\title{
Treatment of Dye Wastewater Containing Chromium from Batik Industry using Coconut Shell Activated Carbon Adsorption
}

\author{
Aulia Qistia ${ }^{*}$, Riza Agung Pribadi ${ }^{a}$, Hamdan Fatah Ali ${ }^{b}$, Yudhi Utomo ${ }^{a}$, Deni \\ Ainur Rokhim
}

a Department of Chemistry, Faculty of Mathematics and Science, Universitas Negeri Malang, Malang, 65145, Indonesia

${ }^{b}$ Department of Biology, Faculty of Mathematics and Science, Universitas Negeri Malang, Malang, 65145, Indonesia

c Chenistry, SMAN 3 Sidoarjo, Indonesia

INFO ARTIKEL

\begin{tabular}{l}
\hline Diterima 05 Desember 2020 \\
Disetujui 30 April 2021 \\
\hline Key word: \\
Batik wastewater \\
Remazol \\
Adsorption \\
Coconut Shell \\
Activated Charcoal \\
\hline
\end{tabular}

*e-mail: auliaqisti00@gmail.com

\begin{abstract}
A B S T R A C T
Batik is a characteristic Indonesian textile product that use dyes. Various types of batik dyes, one of which is remazol dyes. This is what underlies the process of production of the household batik industry in the village of Purwosekar, District of Tajinan, Malang Regency, with remazol coloring will produce liquid waste that is difficult to be deciphered naturally. This study aims to provide a water treatment solution using the coconut shell activated carbon adsorption method to adsorb remazol dyes. Adsorption experiments were carried out in batches with a mesh size of 8 with coconut shell carbon activated with $1 \mathrm{M} \mathrm{HCl}$ solution for 24 hours. The absorption of remazol dyes by coconut shell activated charcoal is carried out with a stirring speed variation (30,60, and $90 \mathrm{rpm}$ ) for 60 minutes and the mass of activated charcoal (200 and $300 \mathrm{~g}$ ) to find the optimum adsorption conditions. The highest efficiency of coconut shell activated charcoal in reducing chromium (Cr) content in batik waste was the treatment of variations in stirring speed of $90 \mathrm{rpm}$ and mass of $300 \mathrm{~g}$ per $1 \mathrm{~L}$ of waste. The $\mathrm{Cr}$ concentration which was initially $0.8154 \mathrm{mg} / \mathrm{L}$ then decreased by $0.2825 \mathrm{mg} / \mathrm{L}$ to $0.5329 \mathrm{mg} / \mathrm{L}$, so that an efficiency of $34.6456 \%$ was obtained. Thus, the efficiency of the coconut shell activated carbon is proportional to the stirring speed and mass of the coconut shell activated carbon used.
\end{abstract}

\section{Introduction}

The development of modern industry has dramatically changed the progress of human civilization. Meanwhile, we also suffer from the dangers of environmental pollution while enjoying the beneficial achievements created by industrial civilization [1]. The textile industry holds a big responsibility for one of the environmental problems, namely water pollution by waste generated from industrial processes [2]. In Indonesia, one of the textile industries is batik.

Batik is a piece of cloth applied with a dyeresistant technique using "batik-wax" media as the holding medium [3]. Synthetic dyes have been used extensively by the industry to produce colorful batik for many years. Naphthol, Soluble, Direct, Remazol, and Reactive Tilapia are dyes commonly used for the batik coloring process [4]. However, Soebaryo reported that there is a skin disorder found in batik factory workers, namely contact dermatitis, and this skin disorder has a strong correlation with the use of synthetic dyes [5].

Most of the batik produced is in the form of Small and Medium Enterprises (UKM) and usually does not have a wastewater treatment plant. Therefore, generally these industries dispose of wastewater directly into the soil or rivers, which has caused pollution $[6,7]$.

These dyes and chemicals, in addition to their unacceptable appearance and toxic effects once damaged, can contaminate nearby soil, sediment, and surface water, posing a major challenge to global environmental pollution. Colored water is unacceptable because it shows changes in the physical properties of water and indicates that water cannot be consumed [8]. 
Metal contamination in textile waste occurs due to the presence of dyes and additives used (for example, caustic soda, sodium carbonate, and salt) during the textile manufacturing stage. The main metals that pose environmental challenges are chromium, zinc, iron, mercury, and lead [9]. However, Adinew reports that the main metals found in chromophore dyes in textile waste are cobalt, copper, and chromium [10].

Chromium compounds, especially in the form of chromium (III) or chromium (VI), are widely used in electroplating, metal finishing, tanning, wood protection, and the manufacture of dyes and catalysts [11]. Cr (VI) has the potential to be a human carcinogen, and its biological toxicity is 1000 times higher than that of $\mathrm{Cr}$ (III) [12]. High Cr (VI) intake can lead to cancer and mutagenicity in humans [11]. Activated carbon is a well-known adsorbent for wastewater treatment due to its large specific surface area and porous structure [13]. In addition, activated carbon tends to absorb various kinds of pollutants from water media [14]. Adsorption on activated carbon is superior to other physical and chemical methods for the removal of organic and inorganic waste from water and wastewater due to its high adsorption efficiency, fast adsorption kinetics, and simple design [15]. Whereas DobrowolskiOtto stated that adsorption of heavy metals to activated carbon was found to be the most effective for separation and enrichment of residual metals from aqueous solutions due to their extended surface area, micropore structure, high adsorption capacity, and high level of surface reactivity [16].

In recent years, there has been interest in using low-cost and abundantly available agricultural waste materials, such as bagasse [17], orange peels [18], rice husks [19], pistachio shells [20], etc., as precursors for the preparation of carbon materials. Coconut shells are also a potential precursor for low-cost activated carbon production due to their excellent natural structure and low ash content and provide a potentially cheap alternative to existing commercial carbon [21]. Coconut shell activated carbon was found to be an effective adsorbent to remove $\mathrm{Cr}$ (VI) and $\mathrm{Ni}$ (II) metal ions from water solution [22].
Therefore, the authors tried to do research to reduce levels of chromium $(\mathrm{Cr})$ in batik industrial wastewater by using an adsorbent in the form of activated carbon. This study was intended to determine the ability of activated carbon to reduce levels of chromium $(\mathrm{Cr})$ in wastewater. From the results of this study, we hope it can provide information to the public, especially batik industry, about wastewater treatment using activated carbon as an adsorbent or adsorbent.

\section{Material and Methods}

The stages in this research are divided into three stages, including the preparation stage, the literature study stage, and the implementation stage. The preparation stage is to identify the problem of the object of research, namely batik waste. In this case, a survey was carried out to the home-scale batik industry around Purwosekar Village, District of Tajinan, Malang Regency. The next stage is to conduct literature studies, compile and submit research proposals, and prepare tools and materials for research such as making artificial waste (figure 1). The third stage is the implementation stage.

\section{Materials and reagents}

Coconut shell charcoal and batik materials such as cloth, wax, remazol dye, and waterglass, are purchased from market in Malang. The chemical reagents and materials such as $\mathrm{HCl}$ and filter paper are collected from Chemistry Laboratory in Department of Chemistry, Faculty of Mathematics and Sciences, Universitas Negeri Malang.

\section{Making artificial batik wastewater}

In this research, we create artificial waste, which can be assumed to be the same as the waste in the field. The tools used include a set of batik-making tools, namely a frying pan, stove, and canting; bucket, used as a place for dyeing and washing; and pans, used to boil water. Meanwhile, the materials needed are cloth for batik media, wax, remazol-type dye, and water glass. Making batik waste is done by making batik then the waste is used as a sample.

Before making batik, the cloth must first be measured and torn according to its length. It is sometimes boiled and dried to soften the fibers 
and allow the material to absorb the wax. The next process is to draw motifs on the cloth using a pencil and outline the motifs and small ornaments made for the first time using a tool called canting. This step is the first staining by soaking the cloth as often as necessary to obtain the desired shade. After drying, the fabric is batik again. The process of beating the fabric and coloring is done in turns. After the last staining, the cloth is boiled to remove the wax, then washed and dried. The water that is discharged in the process is sampled. The sample was taken as much as $1 \mathrm{~L}$ and put in a closed glass bottle.

\section{Wastewater preliminary testing (before treatment)}

Initial characteristics test using waste samples from the batik-making process. Chromium levels in the waste samples were tested by AAS (Atomic Absorption Spectrophotometry) [23]. From these measurements obtained data on the concentration of chromium in units of $\mathrm{mg} / \mathrm{L}$.

\section{Wastewater treatment}

Mass measurement of coconut shell charcoal

Total coconut shell charcoal to be used as adsorbent is weighed using an analytical balance to determine its mass. The charcoal used is $100 \mathrm{~g}$.

\section{Activation of coconut shell charcoal}

$100 \mathrm{~g}$ coconut shell charcoal is activated with activator solution. Making the activator solution using concentrated $\mathrm{HCl}$ [24] which is diluted to a concentration of $1 \mathrm{M}$. Then the weighed coconut charcoal is soaked in $500 \mathrm{~mL}$ $\mathrm{HCl} 1 \mathrm{M}$ solution for 24 hours.

The activated charcoal is then filtered using filter paper and then rinsed using distilled water to remove the activator solution [25]. Furthermore, to remove moisture content, activated charcoal is heated for a certain time [26]. In this experiment, heating in an oven at a temperature of $150-175^{\circ} \mathrm{C}$ for 60 minutes.

Wastewater treatment with coconut shell activated charcoal absorbent

First, weigh the activated charcoal to be used, namely $10 \mathrm{~g}$ and $15 \mathrm{~g}$ three times, respectively. Next, measure the volume of each of the six waste samples that will be treated using a measuring cup. The volume required is as much as $50 \mathrm{~mL}$ per sample. Each sample was inserted into a different beaker glass (table 1). Activated charcoal was added to the sample and then stirred for 60 minutes using a magnetic stirrer with the following conditions:

Table 1. The sample to be processed by adsorption

\begin{tabular}{|c|c|c|c|}
\hline \multirow{2}{*}{$\begin{array}{c}\text { Mass of } \\
\text { Activated } \\
\text { Charcoal }\end{array}$} & \multicolumn{3}{|c|}{ Stirring Speed } \\
\cline { 2 - 4 } & $30 \mathrm{rpm}$ & $60 \mathrm{rpm}$ & $90 \mathrm{rpm}$ \\
\hline $10 \mathrm{~g}$ & $\begin{array}{c}\text { Sample } \\
1\end{array}$ & $\begin{array}{c}\text { Sample } \\
2\end{array}$ & $\begin{array}{c}\text { Sample } \\
3\end{array}$ \\
\hline $15 \mathrm{~g}$ & $\begin{array}{c}\text { Sample } \\
4\end{array}$ & $\begin{array}{c}\text { Sample } \\
5\end{array}$ & $\begin{array}{c}\text { Sample } \\
6\end{array}$ \\
\hline
\end{tabular}

Wastewater final testing (after treatment)

Samples 1-6 were retested using AAS to determine chromium levels after processing with coconut shell-activated charcoal. The $\mathrm{Cr}$ (VI) concentration in the bulk reactor suspension of all samples in the above experiment was measured. After chromium was measured by the colorimetric method in Atomic Absorption Spectrometry (AAS) [27], the final concentration of chromium was obtained in $\mathrm{mg} / \mathrm{L}$ units.

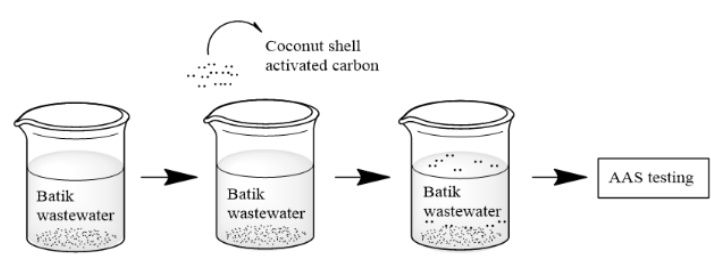

(a)

Figure 1. Processing until retesting of wastewater samples: (a) Pouring sample into beaker glass; (b) Addition of activated carbon to the sample; (c) Stirring process for 60 minutes; (d) AAS testing.

\section{Result and Discussion}

After the activation process, coconut shell charcoal has many cavities or pores. According to Kumrićs research, the morphology of coconut shell activated carbon samples showed particles in the diameter range of less than $\mu \mathrm{m}$ to $120 \mu \mathrm{m}$ [28]. The particles have an irregular 
shape and sharp edges. A rough texture with many pores of different sizes and shapes, as well as shallow and deep cavities, can be observed on the outer surface of the activated carbon. These cavities and pores on the surface increase adsorption. The unique adsorption properties depend on the functional groups of activated carbon present, which are mainly derived from the activation, precursor and thermal purification processes $[29,30]$. Testing the characteristics of batik wastewater was carried out to determine the concentration of $\mathrm{Cr}$ in batik waste. The waste that is used is batik waste from home industry in Purwosekar Village, District of Tajinan, Malang Regency. The results of the analysis of chromium content in the batik waste of Purwosekar Village were tested using AAS (Atomic Absorption Spectrophotometry) with a concentration of $0.8154 \mathrm{mg} / \mathrm{L}$.

From the AAS test data, it can be concluded that the actual $\mathrm{Cr}$ content in this batik waste does not exceed the quality standard threshold for the textile waste category in Indonesia according to the Peraturan Pemerintah Republik Indonesia No. 82 tahun 2001 tentang Pengelolaan Kualitas Air dan Pengendalian Pencemaran Air (The Regulation of The Government of Republic of Indonesia No. 82 year of 2001 on Water Quality Management and Water Pollution Control), namely $1.0 \mathrm{mg} / \mathrm{L}$ [31]. However, this research is still being continued to reduce river waste pollution in Purwosekar Village while preventing more serious pollution that exceeds quality standards.

From the chromium concentration data in batik waste, there is a difference between before processing with activated charcoal and after processing (table 2). After being processed by the adsorption process, the chromium content is reduced. To determine the efficiency of using coconut shell activated charcoal as an adsorbent, it is necessary to analyze and calculate the efficiency. The formula for calculating the efficiency of using activated charcoal to decrease the $\mathrm{Cr}$ concentration showed in equation 1 .

$$
\% \text { efficiency }=\frac{\text { Decreased concentration of } \mathrm{Cr}}{\text { Initial concentration of } \mathrm{Cr}} \times 100 \%
$$

Table 2. The efficiency of reducing the $\mathrm{Cr}$ concentration in the sample

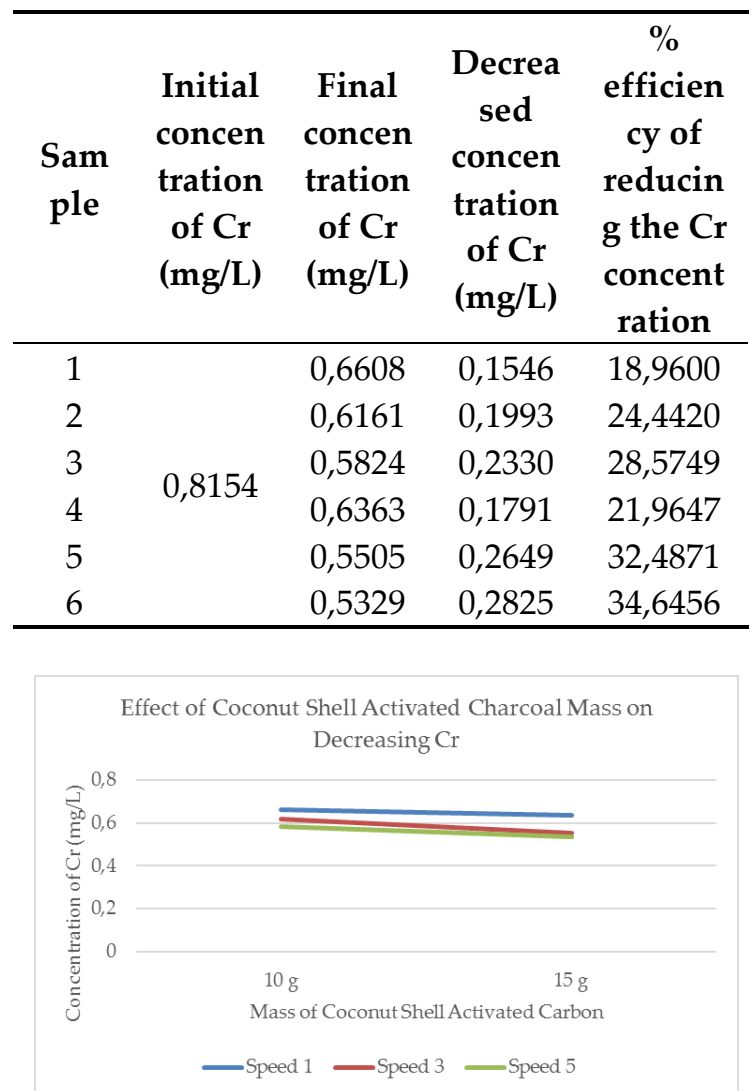

Figure 2. Graph of Effect of Coconut Shell Activated Charcoal Mass on Decreasing $\mathrm{Cr}$

The mass of coconut shell-activated charcoal influences decreasing concentration levels. The greater the mass of coconut shellactivated charcoal, the lower the $\mathrm{Cr}$ concentration (figure 2). From the AAS test data, at speed one, there are samples 1 and 4 . The mass of adsorbent in sample 1 is 10 grams, while in sample 4 is 15 grams. When compared, the $\mathrm{Cr}$ concentration in sample 4 was less, namely $0.6363 \mathrm{mg} / \mathrm{L}$ compared to sample 1 , which was $0.6608 \mathrm{mg} / \mathrm{L}$.

At speed 3, there are samples 2 and 5 . The mass of adsorbent in sample 2 is 10 grams, while in sample 5 is 15 grams. When compared, the $\mathrm{Cr}$ concentration in sample 5 was less, namely $0.5505 \mathrm{mg} / \mathrm{L}$ compared to sample 2, which was $0.6161 \mathrm{mg} / \mathrm{L}$. While at speed 5 there are samples 3 and 6. The mass of adsorbent in sample 3 is 10 grams, while in sample 6 is 15 grams. When compared, the $\mathrm{Cr}$ concentration in sample 6 was less, namely $0.5329 \mathrm{mg} / \mathrm{L}$ compared to sample 3, which was $0.5824 \mathrm{mg} / \mathrm{L}$. This experiment is in line with previous research by Shang [32]. With 
an increase in the adsorbent dose, more phase contact area, adsorption surface area and adsorption site are provided. Optimization of the adsorption of $\mathrm{Cr}$ (VI) from aqueous solutions by activated carbon that has been prepared shows that the initial $\mathrm{Cr}$ (VI) concentration and the adsorbent dose significantly affect the efficiency of $\mathrm{Cr}$ (VI) removal [33].

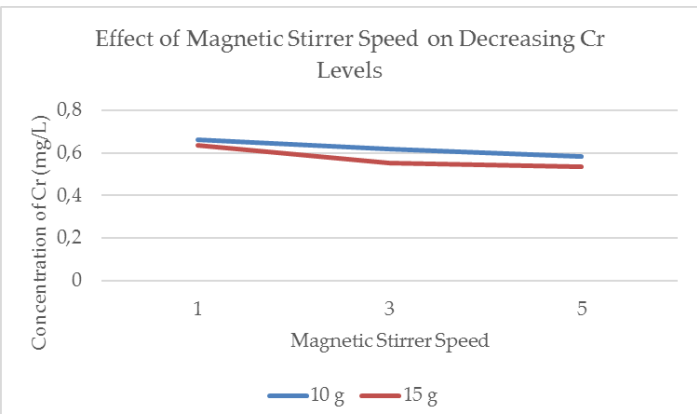

Figure 3. Graph of the Effect of Magnetic Stirrer Speed on Decreasing Cr Levels

From figure 3, the speed of stirring with a magnetic stirrer influences the decrease in concentration levels. The higher the stirring speed, the lower the $\mathrm{Cr}$ concentration. From the AAS test result data, the 10 grams mass data contained samples 1,2 , and 3 . The stirring speed in sample 1 was scale 1 (30 rpm), sample 2 was scale 3 (60 rpm), while sample 3 was scale 5 (90 rpm). When compared, the concentration of $\mathrm{Cr}$ in sample 3 is the lowest, which is $0.5824 \mathrm{mg} / \mathrm{L}$ compared to sample 1 which is $0.6608 \mathrm{mg} / \mathrm{L}$ and sample 2 is $0.6161 \mathrm{mg} / \mathrm{L}$.

Whereas in the 15 grams mass data there are samples 4,5 , and 6 . The stirring speed in sample 4 is a scale of 1 ( $30 \mathrm{rpm})$, in sample 5 is a scale of $3(60 \mathrm{rpm})$, while in sample 6 is a scale of 5 (90 rpm). When compared, the concentration of $\mathrm{Cr}$ in sample 6 is the most a little is $0.5329 \mathrm{mg} / \mathrm{L}$ compared to sample 4 which is as much as $0.6363 \mathrm{mg} / \mathrm{L}$ and sample 5 is as much as $0.5505 \mathrm{mg} / \mathrm{L}$.

This experiment is in line with previous research by Wang [34]. The results showed that higher stirring rate, which provides a stronger impact force, could cause more micellar rods containing the inorganic-organic composite to converge. Higher stirring rates result in larger pores width. The results showed that the larger CMK-3 had a higher specific surface area and pore volume, which led to a higher adsorption capacity and a faster adsorption rate.

Acidic conditions in this case also have an effect on decreasing chromium levels because AC can adsorb chromium only under acidic conditions and under alkaline conditions $(\mathrm{pH}>8)$ [35].

\section{Acknowledgments}

The authors acknowledge Chemistry Department, Faculty of Mathematics and Sciences, Universitas Negeri Malang

\section{Conclusions}

Based on the description above, it can be concluded that the variation of stirring speed and mass variation has an effect in reducing the chromium $(\mathrm{Cr})$ content of batik waste. The higher the stirring speed, the less chrome content in the batik waste. Meanwhile, the greater the adsorbent mass in the form of coconut shell activated charcoal, the less chromium content in the batik waste will be. The highest efficiency of coconut shell activated charcoal in reducing chromium $(\mathrm{Cr})$ content in batik waste was the treatment of variations in stirring speed of $90 \mathrm{rpm}$ and mass of $300 \mathrm{~g}$ per 1 $\mathrm{L}$ of waste. The $\mathrm{Cr}$ concentration, which was initially $0.8154 \mathrm{mg} / \mathrm{L}$, then decreased by 0.2825 $\mathrm{mg} / \mathrm{L}$ to $0.5329 \mathrm{mg} / \mathrm{L}$, so that an efficiency of $34.6456 \%$ was obtained.

\section{References}

1. Wang, W.; Liu, Y.; Liu, X.; Deng, B.; Lu, S.; Zhang, Y.; Bi, B.; Ren, Z. Equilibrium Adsorption Study of the Adsorptive Removal of $\mathrm{Cd} 2+$ and Cr6+ Using Activated Carbon. Environmental Science and Pollution Research 2018, doi:10.1007/s11356-018-2635-5.

2. Yaseen, D.A.; Scholz, M. Textile Dye Wastewater Characteristics and Constituents of Synthetic Effluents: A Critical Review; Springer Berlin Heidelberg, 2019; Vol. 16; ISBN 0123456789.

3. Syahputra, R.; Soesanti, I. Green Energy Approach for Batik Industry in Order to Increase Productivity and Maintain a Healthy Environment. In ICoSI 2014; 2017.

4. Handayani, W.; Kristijanto, A.I.; Hunga, 
A.I.R. Are Natural Dyes Eco-Friendly? A Case Study on Water Usage and Wastewater Characteristics of Batik Production by Natural Dyes Application. Sustainable Water Resources Management 2018, 4, 1011-1021, doi:10.1007/s40899-0180217-9.

5. Soebaryo, R.W. Batik Manufacturing Workers. In Handbook of Occupational Dermatology; 2000.

6. Rashidi, H.R.; Sulaiman, N.M.N.; Hashim, N.A. Batik Industry Synthetic Wastewater Treatment Using Nanofiltration Membrane. Procedia Engineering 2012, doi:10.1016/j.proeng.2012.09.025.

7. Subki, N.S.; Hashim, R.; Muslim, N.Z.M. Heavy Metals Analysis of Batik Industry Wastewater, Plant and Soil Samples: A Comparison Study of FAAS and $\mathrm{HACH}$ Colorimeter Analytical Capabilities. In From Sources to Solution; 2014.

8. Handayani, W.; Kristijanto, A.I.; Hunga, A.I.R. A Water Footprint Case Study in Jarum Village, Klaten, Indonesia: The Production of Natural-Colored Batik. Environment, Development and Sustainability 2019, 21, 1919-1932, doi:10.1007/s10668018-0111-5.

9. Hussein, A.; Scholz, M. Dye Wastewater Treatment by Vertical-Flow Constructed Wetlands. Ecological Engineering 2017, doi:10.1016/j.ecoleng.2017.01.016.

10. Adinew, B. Textile Effluent Treatment and Decolorization Techniques - A Review. Chemistry 2012.

11. Li, H.; Gao, P.; Cui, J.; Zhang, F.; Wang, F.; Cheng, J. Preparation and Cr(VI) Removal Performance of Corncob Activated Carbon. Environmental Science and Pollution Research 2018, 25, 20743-20755, doi:10.1007/s11356-018-2026-y.

12. Markiewicz, B.; Komorowicz, I.; Sajnóg, A.; Belter, M.; Barałkiewicz, D. Chromium and Its Speciation in Water Samples by HPLC/ICP-MS - Technique Establishing Metrological Traceability: A Review since 2000. Talanta 2015.

13. Zeng, G.; Hong, C.; Zhang, Y.; You, H.; Shi, W.; Du, M.; Ai, N.; Chen, B. Adsorptive Removal of $\mathrm{Cr}(\mathrm{VI})$ by Sargassum HorneriBased Activated Carbon Coated with
Chitosan. Water, Air, and Soil Pollution 2020, 231, doi:10.1007/s11270-020-4440-2.

14. Boopathy, R.; Karthikeyan, S.; Mandal, A.B.; Sekaran, G. Adsorption of Ammonium Ion by Coconut ShellActivated Carbon from Aqueous Solution: Kinetic, Isotherm, and Thermodynamic Studies. Environmental Science and Pollution Research 2013, 20, 533-542, doi:10.1007/s11356-012-0911-3.

15. Van, H.T.; Bui, T.T.P.; Nguyen, L.H. Residual Organic Compound Removal from Aqueous Solution Using Commercial Coconut Shell Activated Carbon Modified by a Mixture of Seven Metal Salts. Water, Air, and Soil Pollution 2018, 229, doi:10.1007/s11270-018-3953-4.

16. Dobrowolski, R.; Otto, M. Study of Chromium(VI) Adsorption onto Modified Activated Carbons with Respect to Analytical Application. Adsorption 2010, 16, 279-286, doi:10.1007/s10450-010-9240-3.

17. Gurgel, L.V.A.; Gil, L.F. Adsorption of $\mathrm{Cu}(\mathrm{II}), \mathrm{Cd}(\mathrm{II})$ and $\mathrm{Pb}(\mathrm{II})$ from Aqueous Single Metal Solutions by Succinylated Twice-Mercerized Sugarcane Bagasse Functionalized with Triethylenetetramine. Water Research 2009, doi:10.1016/j.watres.2009.07.017.

18. Ajmal, M.; Rao, R.A.K.; Ahmad, R.; Ahmad, J. Adsorption Studies on Citrus Reticulata (Fruit Peel of Orange): Removal and Recovery of $\mathrm{Ni}(\mathrm{II})$ from Electroplating Wastewater. Journal of Hazardous Materials 2000, doi:10.1016/S0304-3894(00)00234-X.

19. Hassan, A.F.; Mortada, W.I.; Hassanien, M.M. Preparation and Characterization of Activated Carbon Based Rice Husk and Its Use for Preconcentration of $\mathrm{Pt}(\mathrm{II})$. International Journal of Modern Chemistry Int. J. Modern Chem 2013.

20. Dolas, H.; Sahin, O.; Saka, C.; Demir, H. A New Method on Producing High Surface Area Activated Carbon: The Effect of Salt on the Surface Area and the Pore Size Distribution of Activated Carbon Prepared from Pistachio Shell. Chemical Engineering Journal 2011, doi:10.1016/j.cej.2010.10.061.

21. Song, C.; Wu, S.; Cheng, M.; Tao, P.; Shao, M.; Gao, G. Adsorption Studies of Coconut Shell Carbons Prepared by $\mathrm{KOH}$ 
Activation for Removal of Lead(Ii) from Aqueous Solutions. Sustainability (Switzerland) 2014, doi:10.3390/su6010086.

22. Wu, Y.; Yilihan, P.; Cao, J.; Jin, Y. Competitive Adsorption of $\mathrm{Cr}(\mathrm{VI})$ and $\mathrm{Ni}$ (II) onto Coconut Shell Activated Carbon in Single and Binary Systems. Water, Air, and Soil Pollution 2013, 224, doi:10.1007/s11270013-1662-6.

23. Sun, H.-W.; Kang, W.-J.; Ha, J.; Liang, S.-X.; Shen, S.-G. Determination of $\mathrm{Cr}(\mathrm{III})$ and $\mathrm{Cr}(\mathrm{VI})$ in Environmental Waters by Derivative Flame Atomic Absorption Spectrometry Using Flow Injection on-Line Preconcentration with DoubleMicrocolumn Adsorption. Journal of the Iranian Chemical Society 2004, 1, 40-46, doi:10.1007/bf03245769.

24. Wang, F. A Novel Magnetic Activated Carbon Produced via Hydrochloric Acid Pickling Water Activation for Methylene Blue Removal. Journal of Porous Materials 2018, 25, 611-619, doi:10.1007/s10934-0170474-2.

25. Chaudhuri, M.; Azizan, N.K. Bin Adsorptive Removal of Chromium(VI) from Aqueous Solution by an Agricultural Waste-Based Activated Carbon. Water, Air, and Soil Pollution 2012, 223, 1765-1771, doi:10.1007/s11270-011-0981-8.

26. Heidarinejad, Z.; Dehghani, M.H.; Heidari, M.; Javedan, G.; Ali, I.; Sillanpää, M. Methods for Preparation and Activation of Activated Carbon: A Review. Environmental Chemistry Letters 2020, 18, 393-415, doi:10.1007/s10311-019-00955-0.

27. Nguyen, L.H.; Nguyen, T.M.P.; Van, H.T.; $\mathrm{Vu}$, X.H.; Ha, T.L.A.; Nguyen, T.H.V.; Nguyen, X.H.; Nguyen, X.C. Treatment of Hexavalent Chromium Contaminated Wastewater Using Activated Carbon Derived from Coconut Shell Loaded by Silver Nanoparticles: Batch Experiment. Water, Air, and Soil Pollution 2019, 230, doi:10.1007/s11270-019-4119-8.

28. Kumrić, K.; Vujasin, R.; Egerić, M.; Petrović, Đ.; Devečerski, A.; Matović, L. Coconut Shell Activated Carbon as SolidPhase Extraction Adsorbent for Preconcentration of Selected Pesticides from Water Samples. Water, Air, and Soil
Pollution 2019, doi:10.1007/s11270-0194359-7.

29. Bhatnagar, A.; Hogland, W.; Marques, M.; Sillanpää, M. An Overview of the Modification Methods of Activated Carbon for Its Water Treatment Applications. Chemical Engineering Journal 2013.

30. Yousefi, M.; Arami, S.M.; Takallo, H.; Hosseini, M.; Radfard, M.; Soleimani, H.; Mohammadi, A.A. Modification of Pumice with $\mathrm{HCl}$ and $\mathrm{NaOH}$ Enhancing Its Fluoride Adsorption Capacity: Kinetic and Isotherm Studies. Human and Ecological Risk Assessment 2019, doi:10.1080/10807039.2018.1469968.

31. Peraturan Pemerintah Republik Indonesia Peraturan Pemerintah Republik Indonesia Nomor 82 Tahun 2001 Tentang Pengelolaan Kualitas Air Dan Pengendalian Pencemaran Air. 2001

32. Shang, T.X.; Zhang, J.; Jin, X.J.; Gao, J.M. Study of $\mathrm{Cr}(\mathrm{VI})$ Adsorption onto NitrogenContaining Activated Carbon Preparation from Bamboo Processing Residues. Journal of Wood Science 2014, 60, 215-224, doi:10.1007/s10086-014-1392-4.

33. Yusuff, A.S. Optimization of Adsorption of $\mathrm{Cr}(\mathrm{VI})$ from Aqueous Solution by Leucaena Leucocephala Seed Shell Activated Carbon Using Design of Experiment. Applied Water Science 2018, 8, 1-11, doi:10.1007/s13201-018-0850-3.

34. Wang, Q.; Wang, Z.; Zheng, T.; Zhou, X.; Chen, W.; Ma, D.; Yang, Y.; Huang, S. Size Control of SBA-15 by Tuning the Stirring Speed for the Formation of CMK-3 with Distinct Adsorption Performance. Nano Research 2016, 9, 2294-2302, doi:10.1007/s12274-016-1116-8.

35. Mohammad-Khah, A.; Ansari, R. Activated Charcoal: Preparation, Characterization and Applications: A Review Article. International Journal of ChemTech Research 2009.

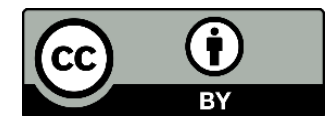

(C) 2021 by the authors. Licensee Fullerene Journal Of Chem. This article is an open access article distributed under the terms and conditions of the Creative Commons Attribution (CC BY) license (http://creativecommons.org/licenses/by/4.0/). 